\title{
A Retrospective Study on Standard Regimen for Vaccination in Celiac Children
}

\author{
Salvatore Leonardi, Giovanna Vitaliti*, Andrea Praticò, Rossella Pecoraro, Mario La Rosa \\ Department of Pediatrics, University of Catania, Catania, Italy. \\ Email: giovitaliti@yahoo.it \\ Received February 12 ${ }^{\text {th }}, 2011$; revised March $29^{\text {th }}, 2011$; accepted April, $6^{\text {th }}, 2011$.
}

\begin{abstract}
Background: HLA system plays an essential role in the human immune system activity and the expression of some specific HLA antigens could modify the immune response to vaccinations. Celiac Disease is included among the diseases associated to specific HLA profiles, principally characterized by the expression of the HLA DQ2 antigen. Object: Our study was a retrospective study, leaded on a group of celiac children, with the object to evaluate their immunological response to both obligatory and recommended vaccinations in childhood. Materials and methods: It was a retrospective study, including 66 patients affected by celiac disease, between 3 and 15 years of age, and a control group of 50 children of the same age. All patients performed both obligatory and recommended vaccinations as indicated in the Italian standard regimen for vaccinations. The immunologic response to each vaccine was analysed and compared in the two groups. Moreover, authors also studied the immunologic response to vaccines in celiac children comparing patients whose diagnosis was made before 18 months of age with those whose disease was diagnosed after 18 months of age. Results: Our results showed that in celiac patients the immunological response to vaccine is similar to that one found in general population, except for $H B V$ vaccine. Conclusions: the valuation of immunological response to $H B V$ vaccine should be regularly effectuated in celiac children and revaccination should be recommended.
\end{abstract}

Keywords: Immune System-Response to Vaccine-Celiac Disease

\section{Introduction}

Actually, in Italy, vaccines are classified as "obligatory vaccinations" and "recommended vaccinations". The first type includes those against Hepatitis B virus, Diphtheria components, Tetanus components and Poliovirus. "Recommended vaccines" are those against Measles virus, Paramixoviridae, Rubella virus, Bordetella Pertussis and Haemofilus Influenzae type B [1].

Human immune response becomes efficient after three weeks the inoculation of the vaccine, reaching its peak of action after some months. The time of protection is variable depending on the used vaccine, and it ranges between one year, in case of Haemophilus Influenzae vaccine, and 10 - 20 years, as for attenuated vaccines, that do not require revaccination [2]. The vaccines that offer a longer protection are those against Measles virus, Paramixoviridae and Rubella virus (the first dose of the combined vaccine for these viruses seems to offer a protection against Measles virus in $90 \%$ - 95\%, Paramixoviridae in $82 \%$ $85 \%$ and Rubella virus in more than $95 \%$ of children who received the vaccine), against Poliovirus and Hepatitis B
Virus. Other vaccines, as that one against Bordetella Pertussis, offer a longer protection (more than 5 years) in pre-scholar age children, considering that in this period of life pathologies can manifest with more serious clinical signs. Other vaccines, as the Tetanus one, have an immunological efficacy lasting more than 30 years, thus it is not necessary a revaccination [2].

HLA system (Human leukocyte antigen) plays an essential role in the identification of the antigens inoculated with vaccines and in the production of specific antibodies $[3,4]$ and some HLA phenotypes seem to be predictive of a less effective immunologic response. A large number of studies underlines that HLA-II haplotypes and homozygosis for alleles HLA-B8, DR3 and DQ2 were found to have a significantly higher incidence of hepatitis B vaccine non-response [3]. Nevertheless it is unknown if these antigens can also negatively influence the concomitant response to other vaccines.

Our study is a retrospective study in which authors wanted to valuate the antibody response to obligatory and recommended vaccines in a paediatric population of patients affected by celiac disease, $95 \%$ of them charac- 
terised by a DQ2 haplotype.

\section{Materials and Methods}

It was a retrospective study, including 66 patients affected by celiac disease, 27 males e 39 females, between 3 and 15 years of age, (medium age: 8.34 years \pm 3.47 DS), followed up in the Pediatric Department of the University of Catania. Diagnosis of Celiac Disease (CD) was made after one year of age, according to ESPHGHAN criteria [5].

All patients received a dose of vaccine against Poliovirus, Hepatitis B virus, Diphtheria and Tetanus components and Bordetella Perutssis, receiving all the inoculations indicated on the Italian standard regimen for vaccinations; 53 patients $(80 \%)$ also received the combined vaccine against Measles Virus, Paramixoviridae and Rubella virus (MPR), and among them only 34 (51\%) received a new dose of vaccine at the age of five years (as indicated on the Italian standard regimen for vaccinations).

Moreover a case control group was studied and it included 50 children in good health conditions, 28 males and 22 females, between 3 and 15 years of age (medium age: 7.58 years $\pm 3.51 \mathrm{SD}$ ) who performed both obligatory and recommended vaccinations, with all doses indicated by the standard regimen for vaccinations.

Anti-polio antibodies were analysed with the neutralization technique. Antibodies against Rubella Virus and Hepatitis B Virus were analysed with the chemiluminescence technique. Antibodies against Measles Virus and Paramixovirus were analysed with ELISA. Antibodies against Diphtheria and Tetanus components and Bordetella Pertussis were evidenced with immunofluorescence assays.

Specific antibodies (IgG) levels were quantified and authors considered responsive:

- Patients with Poliovirus antibodies levels $>0.1 \mathrm{IU} / \mathrm{ml}$

- Patients with diphtheria antibodies levels $>0.1 \mathrm{IU} / \mathrm{ml}$

- Patients with tetanus antibodies levels $>0.01 \mathrm{UI} / \mathrm{ml}$

- Patients with measles virus antibodies levels $>1 / 50$

- Patients with paramixoviridae antibodies levels $>1 / 20$

- Patients with rubella virus antibodies levels $>5 \mathrm{UI} / \mathrm{ml}$

- Patients with Bordetella Perussis antibodies levels $>$ $1 / 50 \mathrm{IU} / \mathrm{ml}$

- Patients with HBs antigen antibody levels $>10 \mathrm{IU} / \mathrm{ml}$

\section{Statistical Analysis}

Mann-Whitney-U- test was used to compare the antibodies title for different vaccines between patients affected by celiac disease and the control group.

Fisher test was used to compare the number of responders and non responders between patients affected by celiac disease and the control group. The same test was used to compare the results between celiac patients whose diagnosis was made before and after 18 months of age.

Results of $p<0.05$ were considered statistically significant.

\section{Results}

Our data showed that in celiac patients the number of responders to both obligatory and recommended vaccinations is similar to that one found in the control group, except for the response to HBV vaccine, that was significantly lower in the celiac group (47\% vs $84 \%$; p < 0.0001) (Table 1).

Antibodies levels too resulted similar in the two groups, except for HBV vaccine, for which the antibody title resulted significantly lower in the celiac group (Table 2).

Moreover it seems that the time of diagnosis influenced the percentage of responders to different vaccinations except for anti-hepatitis B vaccine, for which it was observed a larger number of responders among patients whose diagnosis of Celiac Disease was made at earlier age ( $<18$ months) (Table 3 ).

\section{Discussion}

HLA system plays an essential role in the immunological identification of all non-self antigens in contact with human organism, thus also modifying the immunological response to vaccines, with a selective expression of some HLA molecules $[3,4]$.

In our study we analysed the Celiac Disease (CD) that, as known in literature, is associated with some specific genes of HLA system class II DQ2 and DQ8 [6-8] and more than $95 \%$ of celiac patients shares these two haplotypes $[9,10]$. In literature there are few data that analyses the immunologic response to vaccines in celiac children.

Table 1. Responders to vaccines in the group of celiac patients and control group.

\begin{tabular}{lccc}
\hline & $\begin{array}{c}\text { Celiac Patents } \\
\text { R/NR (\%) }\end{array}$ & $\begin{array}{c}\text { Control Group } \\
\text { R/NR (\%) }\end{array}$ & P value* $^{*}$ \\
\hline $\begin{array}{l}\text { Number of } \\
\text { patients }\end{array}$ & 66 & 50 & \\
Polio & $66 / 0(100 \%)$ & $50 / 0(100 \%)$ & $\mathrm{ns}$ \\
Diphtheria & $66 / 0(100 \%)$ & $50 / 0(100 \%)$ & $\mathrm{ns}$ \\
Tetanus & $66 / 0(100 \%)$ & $50 / 0(100 \%)$ & $\mathrm{ns}$ \\
Hepatitis B & $31 / 35(47 \%)$ & $42 / 8(84 \%)$ & $<0.0001$ \\
Measle & $38 / 15(72 \%)$ & $41 / 9(82 \%)$ & $\mathrm{ns}$ \\
Parotitis & $43 / 10(81 \%)$ & $46 / 4(92 \%)$ & $\mathrm{ns}$ \\
Rubella & $43 / 10(81 \%)$ & $40 / 10(80 \%)$ & $\mathrm{ns}$ \\
Pertussis & $36 / 30(54 \%)$ & $27 / 23(54 \%)$ & $\mathrm{ns}$ \\
\hline
\end{tabular}

$\mathrm{R}=$ responders; $\mathrm{NR}=$ non responders; $*$ Test di Fisher; $\mathrm{ns}=$ not statistically significant. 
Table 2. Immunologic response to vaccines in the two groups.

\begin{tabular}{lccc}
\hline & Celiac patients Medium \pm DS & Control group Medium \pm DS & P value* \\
\hline Vaccine Against Poliovirus & $0.32 \pm 0.11 \mathrm{IU} / \mathrm{ml}$ & $0.38 \pm 0.14 \mathrm{IU} / \mathrm{ml}$ & $\mathrm{ns}$ \\
Vaccine Against Diphtheria Components & $0.07 \pm 0.10 \mathrm{IU} / \mathrm{ml}$ & $0.29 \pm 0.24 \mathrm{IU} / \mathrm{ml}$ & $\mathrm{P}<0.0001$ \\
Vaccine Against Tetanus Components & $0.99 \pm 0.40 \mathrm{IU} / \mathrm{ml}$ & $0.84 \pm 0.62 \mathrm{IU} / \mathrm{ml}$ & $\mathrm{ns}$ \\
Hbv Vaccine & $103 \pm 218.4 \mathrm{IU} / \mathrm{ml}$ & $266 \pm 355.8 \mathrm{IU} / \mathrm{ml}$ & $\mathrm{P}<0.003$ \\
Vaccine Against Measle Virus & $1 / 100 \pm 1 / 100$ & $1 / 20 \pm 1 / 50$ & $\mathrm{~ns}$ \\
Vaccine Against Paramixoviridae & $1 / 50 \pm 1 / 50$ & $1 / 20 \pm 1 / 50$ & $\mathrm{~ns}$ \\
Vaccine Against Rubella Virus & $280.18 \pm 621.8 \mathrm{IU} / \mathrm{ml}$ & $129.4 \pm 132.4 \mathrm{IU} / \mathrm{ml}$ & $\mathrm{ns}$ \\
Vaccine Against Bordetella Pertussi & $1 / 30 \pm 0.03 \mathrm{IU} / \mathrm{ml}$ & $1 / 30 \pm 0.03 \mathrm{IU} / \mathrm{ml}$ & $\mathrm{ns}$ \\
\hline
\end{tabular}

ns $=$ not statistically significant; *test di Mann-Whitney

Table 3. Age at diagnosis of celiac disease and number of responders to $\mathrm{HBV}$ vaccine.

\begin{tabular}{cccc}
\hline & Responders & $\begin{array}{c}\text { Non } \\
\text { Responders }\end{array}$ & p value $^{*}$ \\
\hline $\begin{array}{c}\text { Age at diagnosis }<\mathbf{1 8} \\
\text { months }\end{array}$ & 16 & 6 & $\begin{array}{c}\mathrm{P}= \\
\text { Age at diagnosis }>\mathbf{1 8} \\
\text { months }\end{array}$ \\
\hline
\end{tabular}

*Test di Fisher

Park et coll. [11] described that more than 50\% of children with $\mathrm{CD}$ do not show a response to standard vaccination regimens for $\mathrm{HBV}$, while the response to vaccinations against Rubella virus, Clostridium Tetani and $\mathrm{H}$. Influenzae type $\mathrm{B}$ was normal. These results seemed to underline that the HLA haplotype of CD patients plays a negative role only concerning the response against HBV vaccine [12,13].

Our study demonstrates that the response to obligatory and recommended vaccines is similar to that of the general population, except for HBV vaccine. Antibodies levels are generally lower in the group of celiac children rather than the control group, even if this difference is not statistically significant, except for HBV vaccine. Moreover authors have observed that the response to Pertussis vaccine is low (54\%) in the celiac group but similar to that one found in the control group. This finding indicates that the HLA system of patients affected by CD is not directly responsible for the low response to this vaccine.

The immunologic response does not seem to be influenced by the natural history of CD. As a matter of fact an early ( $<18$ months of age) or a delayed diagnosis (over 18 months of age) does not significantly modify the immunologic response, except for that one involved in the HBV vaccination.

With regards to this affirmation, it is still unclear the role of gliadin peptides on the response to $\mathrm{HBV}$ vaccine and if a delayed diagnosis of CD in association with homozygosis for DQ2, are primary causes of the fail of the response to $\mathrm{HBV}$ vaccine $[14,15]$.
Nemes e coll. [16] demonstrated that the rate of nonresponse celiac patients to the standard regimen of recombinant $\mathrm{HBV}$ vaccination was surprisingly high $(74.1 \%)$, in undiagnosed and untreated celiac adolescents. Moreover they demonstrated that a normal responder rate $(95.5 \%)$ was achieved by prospective immunization on a gluten free diet and the non response rate was only $49.1 \%$ when HBV immunization was performed unrelated to diagnosis and diet status. At regard, in fact, literature data showed that both Hbs surface antigens and gliadin peptides bind with HLA-DQ2, thus that their competition can cause a defective immunological response.

On the contrary, in another study leaded on adult patients, Noh e coll [17] demonstrated that CD itself did not seem to have an important role in unresponders to HBV vaccine because the altered immune response to the vaccine seemed to be independent from the intake of gluten.

Ahishali e coll [18] emphasized the involvement of genetic specifications in unresponsiveness to $\mathrm{HBV}$ vaccination, because half of the patients who had autoimmune disease along with $\mathrm{CD}$ were unresponders to $\mathrm{HBV}$ vaccine.

\section{Conclusions}

Our study confirms that the immunological response to vaccines of children affected by celiac disease is generally similar to that one of general population and antibodies titles are sufficiently high to give a lasting protection.

On the contrary the response of $\mathrm{CD}$ patients to $\mathrm{HBV}$ vaccine is significantly lower than the response of general population, even though the pathogenic mechanism still remains unknown.

As these data are of high clinical interest, an analysis of the response to HBV vaccine should be considered in children affected by $\mathrm{CD}$ and revaccination should be recommended.

\section{REFERENCES}

[1] G. Ada, "Vaccines and Vaccination," The New England Journal of Medicine, Vol. 345, No. 14, October 2001, pp. 1042-1053. doi:10.1056/NEJMra011223 
[2] P. Letontourier, "Vaccination from Theory to Practice," Presse med, Vol. 34, 2005, p. 547.

[3] C. Wang, J. Tang, W. Song, E. Lobashevsky, C. M. Wilson and R. A. Kaslow, "HLA and Cytokine Gene Polymorphisms are Independently Associated with Responses to Hepatitis B Vaccination," Hepatology, Vol. 39, No. 4, April 2004, pp. 978-988. doi:10.1002/hep.20142

[4] A. Herman, J. W. Kappler, P. Marrak and A. M. Pullen, "Superantigens: Mechanisms of T-Cellstimulation and Role in Immune Response," Annual Review of Immunology, Vol. 9, 1991, pp. 745-772. doi:10.1146/annurev.iy.09.040191.003525

[5] K. E. Lundin, H. A. Gjertsen, H. Scott, L. M. Sollid and E. Thorsby, "Function of DQ2 and DQ8 as HLA Susceptibility Molecules in Celiac Disease," Human immunology, Vol. 41, No. 1, 1994, pp. 24-27. doi:10.1016/0198-8859(94)90079-5

[6] N. P. Radlović, et al., "Influence of Early Feeding Practices on Celiac Disease in Infants," Archives of Disease in Childhood, Vol. 65, 1990, pp. 909-911. doi:10.1136/adc.65.8.909

[7] L. M. Sollid and E. Thorsby, "HLA Susceptibility Genes in Celiac Disease: Genetic Mapping and Role in Pathogenesis," Gastroenterology, Vol. 105, No. 3, 1993, pp. 910-922

[8] S. Caillat-Zucman, "Molecular Mechanisms of HLA Association with Autoimmune Diseases," Tissue Antigens, Vol. 73, No. 1, 2009, pp. 1-8. doi:10.1111/j.1399-0039.2008.01167.x

[9] K. Kaukinen, J. Partanen, M. Maki and P. Collin, "HLA-DQ Typing in the Diagnosis of Celiac Disease," American Journal of Gastroenterology, Vol. 97, 2002, pp. 695-699. doi:10.1111/j.1572-0241.2002.05471.x

[10] E. J. Hoffenberg, T. Mackenzie, K. J. Barriga, G. S. Eisenbarth, F. Bao, J. E. Haas, H. Erlich, T. T. Bugawan, R. J. Sokol, I. Taki, J. M. Norris and M. Rewers, "A Prospective Study of the Incidence of Childhood Celiac Disease," The Journal of Pediatrics, Vol. 143, No. 3, September 2003, pp. 143:308-314.

[11] S. D. Park, J. Markowitz, M. Pettei, T. Weinstein, C. P. Sison, S. R. Swiss and J. Levine, "Failure to Respond to
Hepatitis B Vaccine in Children with Celiac Disease," Journal of Pediatric Gastroenterology \& Nutrition, Vol. 44, No. 4, 2007, pp. 431-435 doi:10.1097/MPG.0b013e3180320654

[12] M. Martinetti, A. De Silvestri, C. Belloni, A. Pasi, C. Tinelli, A. Pistorio, L. Salvaneschi, G. Rondini, M. A. Avanzini and M. Cuccia, "Humoral Response to Recombinant Epatitis B Virus Vaccine at Birth: Role of HLA and Beyond," Clinical Immunology, Vol. 41, 2000, pp. 1383-1390.

[13] A. Safary and F. Andre, "Over a Decade of Experience with a Yeast Recombinant Hepatitis B Vaccine," Vaccine, Vol. 18, No. 1-2, August 1999, pp. 57-67. doi:10.1016/S0264-410X(99)00179-6

[14] S. Leonardi, M. Spina, L. Spicuzza, N. Rotolo and M. La Rosa, "Hepatitis B Vaccination Failure in Celiac Disease: Is There a Need to Reassess Current Immunization Strategies?" Vaccine, Vol. 27, No. 43, October 2009, pp. 6030-6033. doi:10.1016/j.vaccine.2009.07.099

[15] A. Godkin, M. Davenport and A. V. Hill, "Molecular Analysis of HLA Class II Associations with Hepatitis B Clearance and Vaccine Non Responsiveness," Hepatology, Vol. 41, No. 6, June 2005, pp. 1383-1390. doi:10.1002/hep.20716

[16] E. Nemes, E. Lefler, L. Szegedi, A. Kapitány, J. B. Kovács, M. Balogh, K. Szabados, J. Tumpek, S. Sipka and I. R. Korponay-Szabó, "Gluten Intake Interferes with the Humoral Immune Response to Recombinant Hepatitis B Vaccine in Patients With Celiac Disease," Pediatrics, 121, No. 6, June 2008, pp. 1570-1576 doi:10.1542/peds.2007-2446

[17] K. W. Noh, G. A. Poland and J. A. Murray, "Hepatitis B Vaccine Nonresponse and Celiac Disease," American Journal of Gastroenterology, Vol. 98, 2003, pp. 22892292. doi:10.1111/j.1572-0241.2003.07701.x

[18] E. Ahishali, G. Boztas, F. Akyuz, D. Ibrisim, S. Poturoglu, B. Pinarbasi, S. Ozdil and Z. Mungan, "Response to Hepatitis B Vaccination in Patients with Celiac Disease," Digestive Diseases and Sciences, Vol. 53, No. 8, 2008, pp. 2156-2159. doi:10.1007/s10620-007-0128-3 